\title{
THE DEVELOPMENT OF LEARNING MEDIA OF PANJAT PINANG BIO BOARD GAMES AT THE CLASS XI OF MA GUPPI SAMATA
}

\author{
Ainul Uyuni Taufiq ${ }^{1}$, Asniati Jabbar ${ }^{2}$, Zulkarnaim ${ }^{3}$ \\ 1,2,3Universitas Islam Negeri Alauddin Makassar \\ 1,2,3Jalan H. M. Yasin Limpo No. 36, Romang Polong-Gowa, Sulawesi Selatan \\ Email: ainul.uyuni@uin-alauddin.ac.id11, asniatijabbar18@gmail.com², \\ zulkarnaim.umar@uin-alauddin.ac.id ${ }^{3}$
}

\begin{abstract}
:
This research aimed to: (1) develop learning media of Panjat Pinang Bio Board Games based on circulation system material for class XI of MA GUPPI Samata, (2) determine the level of validity, practicality, and effectiveness of Panjat Pinang Bio Board Games. The research method employed was Research and Development (R \& D) with the 4-D development model, namely define, design, develop, and disseminate. The instruments used were validation sheets, educator and student questionnaires, and questions. The population was 24 students of class XI, and six students were selected as samples. The results indicated that the average validity level was 3.62 with valid category, while the average practicality level was 3.10 with practical category. The level of efficacy was $100 \%$ which fulfilled the completeness criteria with effective category. Therefore, Panjat Pinang Bio Board Games was considered practicable to employ since it matched the criteria of being valid, practical, and effective. Selecting appropriate learning media supports students' learning outcomes.
\end{abstract}

\begin{abstract}
Abstrak:
Penelitian bertujuan (1) mengembangkan media pembelajaran Bio Board Gamess Panjat Pinang pada materi sistem sirkulasi kelas XI MA pesantren GUPPI Samata, (2) mengetahui tingkat kevalidan, kepraktisan, dan keefektifan media pembelajaran Bio Board Gamess Panjat Pinang pada materi sistem sirkulasi kelas XI MA pesantren GUPPI Samata. Metode penelitian yaitu research and development (R \& D) dengan model pengembangan 4-D yaitu define, design, develop dan disseminate. Instrumen penelitian yang digunakan di antaranya lembar validasi, angket respon pendidik dan peserta didik, dan soal. Populasi dalam penelitian ini adalah siswa kelas XI dan terpilih 6 orang sebagai sampel. Hasil penelitian menunjukkan tingkat validitas 3,62 dengan kategori valid, tingkat kepraktisan rata-rata 3,10 dengan kategori praktis. Tingkat keefektifan mencapai 100\% yang memenuhi nilai KKM dengan kategori efektif. Sehingga media pembelajaran Bio Board Gamess Panjat Pinang layak digunakan karena memenuhi kriteria valid, praktis dan efektif. Pemilihan media pembelajaran yang tepat mendukung hasil belajar siswa.
\end{abstract}

\section{Keywords:}

Development, Learning Media

How to Cite: Taufiq, A. U., Jabbar, A., \& Zulkarnaim. (2021). The Development of Learning Media of Panjat Pinang Bio Board Games at The Class XI of MA Guppi Samata. Lentera Pendidikan : Jurnal Ilmu Tarbiyah dan Keguruan, 24(2), 169-177. https://doi.org/10.24252/lp.2021v24n2i1. 


\section{INTRODUCTION}

Education is an effort to mold civilized and moral human beings with the primary purpose of humanizing humans. Thus, education is used to educate and enhance the overall quality of the nation's youngsters. Students are expected to be able to apply what they learn in the classroom to their family environment, the larger community, the nation, and most importantly, to themselves (Saondi \& Suherman, 2015). Education is not only about imparting knowledge and honing skills; it is also about developing a person's capacity for a fulfilling personal and social life (Oemar, 2011). Therefore, education aims to foster Indonesia's national development through an endeavor to educate the populace in order to acquire superior human resources (Chomaidi \& Salamah, 2018).

Education as a form of continuous learning certainly involves many components. Those components include students (raw input), instrumental input such as educators, goals, curriculum, methodologies, and school facilities, as well as environmental input such as the situations that arise during the learning process and the implementation of education (Yusuf, 2015).

Educators, in their capacity as facilitators, must provide learning resources that facilitate the learning process, such as reading books and learning media (Kirom, 2017). Educators implementing learning in the classroom require a learning device, such as learning media, to be used during teaching activities because media is a significant factor affecting learning activities (Mahmud, 2012). With the interaction that occurs, it will be simple to accomplish the learning objectives and obtain satisfactory results (Pane \& Dasopang, 2017).

Biology is a subject taught in junior high schools as part of integrated science and is also studied in high schools as part of the science curriculum. Biology is the study of nature, with a focus on living and non-living organisms. Thus, biology is a complex science comprised of both theories and facts. Biology for students is seen as a tough lesson to comprehend because there are numerous subjects and limited time, and educators merely offer material without attempting to stimulate students' interest in studying. Due to a lack of facilities and infrastructure, lessons cannot be produced, and the resulting influence on students' achievement is not optimal (Relisa, 2017).

Students encounter obstacles throughout the learning process; two aspects contribute to this: internal factors such as attitudes during the learning process, learning motivation, self-confidence, and comprehension level of the learning topic. While the second aspect is external, it includes the environment, school curriculum, educators, facilities, and infrastructure (Zikra, 2016). Learning media refers to media that work as an intermediate in distributing educational materials from educators to students (Adam \& Syastra, 2015). There are several types of learning media: the first type is graphic media such as posters, charts, comics, and pictures, as well as two-dimensional media; the second type is three-dimensional learning media, which includes solid models; the third type is projection models, which includes slides; and the fourth type is environment as a learning medium (Karo-Karo \& Rohani, 2018). 
The use of media enables educators to provide lessons and explanations to students more readily. It also enables educators to communicate with one another in order to foster reciprocal interactions (Tafonoa, 2018). The use of media in education can assist in explaining complex concepts and can help overcome the wasteful use of time during the learning process (Sadiman, Rahardjo, Haryono, \& Harjito, 2012). Learning packed in learning media requires students to take an active role and provides challenges for students, allowing them to get experience being creative and integrating with other students (Shafira, Rosayanti, \& Baedowi, 2018).

As a result of observations at the MA (Islamic High School) of GUPPI Samata, it is recognized that there were difficulties with learning activities. Due to a lack of learning media on circulation system material, educators typically teach using the lecture method. Educators more often provide material through books so that students tend to participate less actively in class during the learning process and have a lack of excitement for learning.

Based on the existing challenges, it is necessary to develop innovative learning media capable of fostering and reawakening students' interest in learning in the circulation system's material. The media are the Panjat Pinang Bio Board Games, which incorporate elements of collaboration, competition, and cooperation. Collaborative refers to cooperation between students in their respective groups to foster positive relationships with group members; competitive means to healthy competition between groups in order for each group to work diligently to earn the highest possible points; and cooperative relates to students having responsibilities within the group by adhering to all applicable regulations.

Akbar \& Irawan (2017) conducted a similar study entitled "Development of Panjat Pinang Game Media." The use of media is considered appropriate to provide material for the circulation system in class. The Panjat Pinang Bio Board Games is supposed to boost the spirit of learning and inspire students to be active in the classroom to create effective learning. Media board games are expected to make children remember the information conveyed in the long term. Students can get information using board games properly and correctly. The usage of board games that require students to think and strategize strengthens their abilities during the learning.

The development of media in this study is distinct from other studies. Did research to communicate about driving safety through board game media so that the development of board games developed was also different. Created dice-rolling board games. Additionally produced board games with different concepts and game rules from the previously developed board games. Meanwhile, produced board games for children aged 6-10 years to simplify the designs and maintain their learning interests. The developed media are customized to the research subject and the content to be delivered in order to accomplish the development objectives.

This research aimed to develop learning media of Panjat Pinang Bio Board Games on the circulation system material for the students of GUPPI Samata. The objectives were to find out the level of validity, practicality, and efficacy of the learning media of Panjat Pinang Bio Board Games on the circulation system material for the students of MA GUPPI Samata. 


\section{RESEARCH METHOD}

The method used was Research and Development to develop a valid, practical, and effective Bio Board Games learning media product. The research design used was the 4-D model with four stages; they were defined, design, develop, and disseminate (Trianto, 2017). The 4-D development model is the right guide for creating media since it includes clear, comprehensive, and precise steps that ensure effective application. Additionally, the development procedure is relatively quick. The population of this study was 24 students of class XI at MA GUPPI Samata, and the sample selected was six students, $25 \%$ of the total population. A validation sheet was used to determine the media's credibility. This research used questionnaire responses for educators and students to assess the media's practicality and used instruments in the form of questions to assess the media's level of efficacy.

Validity, practicality, and effectiveness tests were used to analyze the data. Two validators were involved in determining validity. Table 1 describes the validity data analysis technique applied.

Annotation:

$$
\overline{K i} \quad=\frac{\sum_{j}^{n}=1 V_{i j}}{n}
$$

$\overline{K i}=$ the average of criterion $\mathrm{i}$

$V_{i j}=$ the assessment result score of $\mathrm{i}$ criterion by $\mathrm{j}$ evaluator

$\mathrm{N}=$ the total number of evaluators

Table 1. Criteria Level of Validity

\begin{tabular}{cc}
\hline Score & Criteria \\
\hline $3.5 \leq M \leq 4$ & Very valid \\
$2.5 \leq M \leq 3.5$ & Valid \\
$1.5 \leq M \leq 2.5$ & Quite valid \\
$M \leq 1.5$ & Invalid \\
\hline
\end{tabular}

The practicality of the media was determined based on the results of educators' and students' questionnaire responses. Table 2 presents the data analysis used.

Annotation:

$$
\mathrm{X}_{\mathrm{i}}=\frac{\sum_{i=0}^{n} A i}{n}
$$

$\mathrm{Ai}=$ the average of aspects

$\mathrm{n}=$ the total number of aspects

Table 2. Criteria Level of Practicality

\begin{tabular}{cc}
\hline Score & Criteria \\
\hline $3.5 \leq \mathrm{X}_{\mathrm{i}} \leq 4$ & Very Practical \\
$2.5 \leq \mathrm{X}_{\mathrm{i}} \leq 3,5$ & Practical \\
$1.5 \leq \mathrm{X}_{\mathrm{i}} \leq 2,5$ & Quite Practical \\
$0 \leq \mathrm{X}_{\mathrm{i}} \leq 1,5$ & Impractical \\
\hline
\end{tabular}

The media effectiveness was measured based on the students' learning outcome test. Students gained at least $80 \%$ of the teaching process in class, ensuring that they 
received a passing grade (Widoyoko, 2012). Table 3 illustrates data analysis of effectiveness applied.

$$
\mathrm{N}=\frac{W}{n}
$$

Notation:

$\mathrm{N}=$ students' scores

$\mathrm{W}=$ the total number of correct answers

$\mathrm{n}=$ the total number of questions

Table 3. Criteria Level of Effectiveness

\begin{tabular}{cc}
\hline $\begin{array}{c}\text { Completeness } \\
\text { Percentage }\end{array}$ & Classification \\
\hline$>80$ & Very effective \\
$>60-80$ & effective \\
$>40-60$ & Quite effective \\
$>20-40$ & Less effective \\
$20 \leq$ & ineffective \\
\hline
\end{tabular}

\section{RESULTS AND DISCUSSION}

The development of Panjat Pinang Bio Board Games followed the four-stage process: defining, designing, creating, and spreading. The 4-D model is a systematic learning model; it is selected systematically and under existing theoretical foundations. Using the 4-D model, it was discovered that there were efforts being made in the classroom to solve learning problems that were consistent with existing problems, for example, problems with learning resources and teaching materials (Arywiantari, Agung, \& Tastra, 2015).

The first stage was the defining stage, which consisted of preliminary-final analysis to comprehend the difficulties encountered and find solutions (Mirojiyah, 2016). By doing the personality analysis of the testing sample, it was known that the student level of understanding was moderate. Then, the concept analysis became a reference for choosing the suitable sub-chapters for the subject. Additionally, the analysis of tasks concerning the circulation system was conducted. The final step was to define learning objectives.

The second stage was to design prototype I of Panjat Pinang Bio Board Games. This step was used to select the media and to define all characteristics of the media to be developed. It included the shape and size choices that look attractive and practical to use by students.

Development was the third stage. The researchers developed prototype I, which was then validated by two validators to solicit feedback and suggestions. After modifying the media in response to ideas and input, the valid prototype II was developed for testing. Figure 1 summarizes the results of prototype II. 


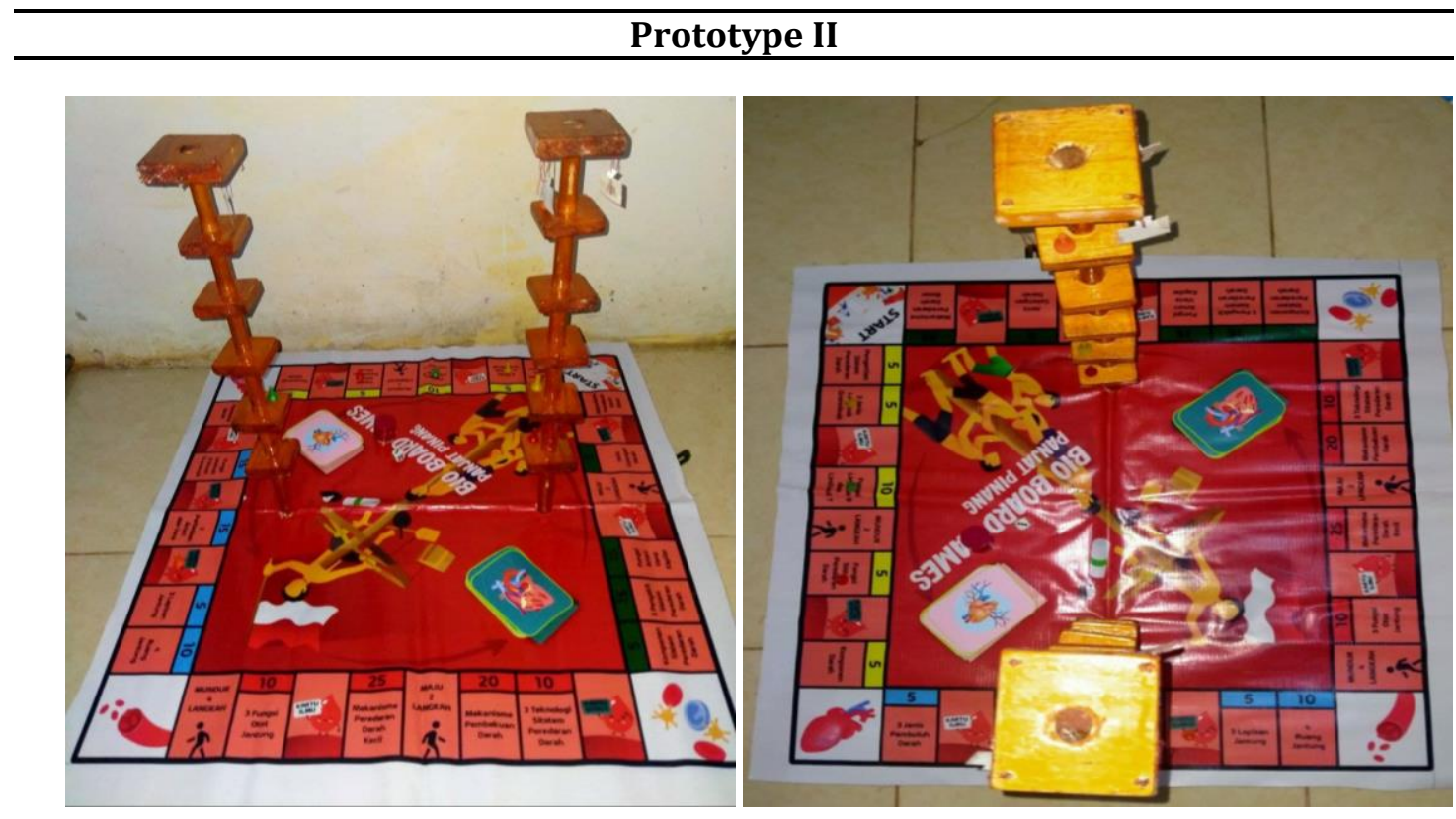

Figure 1. Prototype II

The fourth stage, dissemination, was conducted by researchers in class XI MA GUPPI Samata. The testing was conducted to determine the extent to which Panjat Pinang Bio Board Games could be used as learning media. The total number of students in class XI MA GUPPI Samata was 24. Due to COVID-19 issue, the maximum number of students attending was 6 as samples.

The average validity score for Panjat Pinang Bio Board Games was 3.62. The criteria to determine the media's level of validity reached $1.5 \leq \mathrm{M} \leq 2.5$ with quite valid criteria (Arifin, 2017). If it was within the range of $3.5 \leq \mathrm{M} \leq 4$, it could be considered very valid (Sugiyono, 2013). The learning media developed was classified as very valid due to several reasons: 1 ) The curriculum used was appropriate; 2 ) Students were motivated to learn and participate actively in learning activities; and 3) Learning activities were student-centered (Dwijayani, 2017). Additionally, media was deemed valid if it received a good review for its material and media qualities (Listiani \& Prihatnani, 2018). Interesting media received a good response from students. Table 4 summarizes the validators' assessment.

Table 4. The Average of Validators' Assessments

\begin{tabular}{ccc}
\hline Assessment Aspect & Result & Category \\
\hline Content of media & 4 & Very valid \\
Language/Communication & 3.5 & Valid \\
Presentation & 4 & Very valid \\
Effect for learning strategies & 3.12 & Valid \\
Full view & 3.5 & Valid \\
Average & 3.62 & Very Valid \\
\hline
\end{tabular}


The practicality of the Bio Board Games was determined by the questionnaire responses from students and educators. Their responses were 2.66 and 3.55, respectively. In the practical category, the total response result was 3.10 with intervals $(2.5 \leq \mathrm{Xi} \leq 3.5)$. Practically, the developed media, Panjat Pinang Bio Board Games, was supported by its ease to use (Haviz, 2013). Additionally, media was considered practical if the results of the practicality test receive a good response from educators and students with at least positive criteria (Hidayah, Utami, Qohar, \& Nasution, 2016). Table 5 presents the responses' results.

Tabel 5. The results of total responses

\begin{tabular}{rlc}
\hline No. & Research Respondents & Mean Score \\
\hline 1. & Students & 3.55 \\
2. & Educators & 2.66 \\
Average & 3.10 \\
Assessment Category & Positive \\
\hline
\end{tabular}

The success of Panjat Pinang Bio Board Games as learning media was determined by the students' comprehension level of a topic. This study should be conducted on 24 students of class XI at MA GUPPI Samata. Due to the COVID-19 issue, the maximum number of students attending was six as samples. However, this research continued as stated by Setyosari (2016) that specific sample sizes, such as $10 \%, 15 \%, 20 \%$, etc., could be employed if there were rational reasons. This opinion was supported by Mustami (2015), which indicated that although considerations had been made regarding sample size, definitive criteria regarding sample size could not be decided at this time. The applicable guidelines typically vary between $2 \%$ and $20 \%$, depending on the certain situation and considerations.

The research instrument was the questions. Those questions utilized in a lesson were multiple choices with a total of 20 numbers. In class XI of MA GUPPI Samata, the percentage of students achieving learning outcomes was $100 \%$. If the Participant's KKM score (standard completeness of passing grade) was equal to or greater than 75 , the exercise is considered successful. The results indicated that the percentage of learning outcomes was $100 \%$, which was a very effective criterion. Table 6 shows the percentage of learning outcomes.

Table 6. The Percentage of Student Learning Outcomes

\begin{tabular}{ccc}
\hline Student Completeness & Jumlah & Percentage (\%) \\
\hline Completed & 6 students & $100 \%$ \\
incomplete & - & - \\
Total & 6 students & $100 \%$ \\
\hline
\end{tabular}

Board game media can develop students' critical thinking abilities and help them grasp concepts through experience. The use of gaming media in education is effective learning strategies to get good outcomes. Learning media motivate students and aid in their comprehension. Additionally, educational media might encourage students to be more active (Tafonoa, 2018). 


\section{CONCLUSION}

This research concluded that the learning media of Panjat Pinang Bio Board Games developed using the 4-D model consisting of four stages, namely defining, designing, developing, and disseminating. The level of validity was 3.62, so it was feasible to use. The level of practicality of the media was 3.10 , so that the media was considered practical to use. The level of effectiveness of Panjat Pinang Bio Board Games was 100\%, which was indicated effective category.

\section{REFERENCES}

Adam, S., \& Syastra, M. (2015). Utilization of Information Technology-Based Learning Media for Class X Students of SMA Ananda Batam. CBIS Journal, 3(2). http://ejournal.upbatam.ac.id/index.php/cbis/article/view/400.

Akbar, D. S., \& Irawan, B. (2017). Development of Panjat Pinang Game Media. Educational Journal, 2(1). https://doi.org/10.17977/jptpp.v2i10.10073.

Arifin, Z. (2017). Instrument Criteria in a Research. THEOREMS Journal, 2(1). https://doi.org/10.31949/th.v2i1.571.

Arywiantari, D., Agung, A. G., \& Tastra. (2015). Development of Interactive Multimedia Learning Model 4D In Ipa In Smp Negeri 3 Singaraja. E-Journal of Ganesha University of Education Edutech, 3(1). https://doi.org/10.23887/jeu.v3i1.5611.

Chomaidi, \& Salamah. (2018). Education and Teaching of School Learning Strategies. Jakarta: PT Raja Grafindo Persada.

Dwijayani. (2017). ICARE Learning Media Development. Journal of Creative Innovative Mathematics, 8(2). https://journal.unnes.ac.id/nju/index.php/kreano/article/vie $\mathrm{w} / 10014$.

Haviz, M. (2013). Research and Development Research in the Field of Education that is Innovative, Productive and Meaningful. Ta'dib Journal, 16(1). https://doi.org/10.31958/jt.v16i1.235.

Hidayah, I, N., Utami., T., Qohar, A., \& Nasution, S. (2016). Development of Learning Media. Journal of Mathematics Education, 3(1).

Karo-Karo S., I. R., \& Rohani. (2018). Benefits of Media in Learning. Journal of AXIOM, 7(1).

Kirom, A. (2017). The Role of Teachers and Students in Multicultural-Based Learning Processes. Journal of Islamic Religious Education, 3(1). http://journal.um.ac.id/index.php/jptpp/article/view/10073.

Listiani, D., \& Prihatnani, E. (2018). Development of Dart Board Math Learning Media for Class VII Junior High School Students. Journal of Mathematics Education, 4(1). https://doi.org/10.33654/math.v4i1.80.

Mahmud. (2012). Educational Psychology. Bandung: Setia Pustaka.

Mirojiyah, F. (2016). Multipresentation-Based Module Development in Physics Learning in High Schools. Journal of Development, 3(1). https://jurnal.unej.ac.id/index.php/JP F/article/view/3709.

Mustami, K. (2015). Educational Research Methodology (Cet. I). Yogyakarta: Aynat Publishing. 
Oemar, H. (2011). Curriculum and Education. Jakarta: PT Bumi Aksra.

Pane, A., \& Dasopang, M. (2017). Study and Learning. Journal of Islamic Studies, 3(1). http://journals.ukitoraja.ac.id/index.php/jkip/article/view/66/9.

Relisa. (2017). The Study of Elementary School Educational Infrastructure as One of the Indicators of Achieving National Education Standards. Journal of Education and Culture, 3(1). http://journals.ukitoraja.ac.id/index.php/jkip/article/view/66/9.

Sadiman, A., Rahardjo, R., Haryono, A., \& Harjito. (2012). Educational Media. Jakarta: PT Raja Grafindo Persada.

Saondi, O., \& Suherman, A. (2015). Teaching Profession Ethics. Bandung: PT Refika Aditama.

Setyosari, P. (2016). Educational Research \& Development Methods (Cet. V). Jakarta: Prenada Media Group.

Shafira, A., F, R., \& Baedowi, S. (2018). The Effect of Picture And Picture Learning Model Assisted by the Fortune Wheel Game Media on Activities and Learning Outcomes in the Concept of Animal Life Cycles for Class IV Students. Journal Of Primary And Children's Education, 1(2). http://jurnal.unw.ac.id:1254/index .php/janacitta/article/view/20/79/.

Sugiyono. (2013). Educational Research Methods Quantitative Approach, qualitative and $R \& D$. Bandung: Alfabeta.

Tafonoa, T. (2018). The Role of Learning Media in Increasing Students' Interest in Learning. Journal of Educational Communication, 3(2). http://journal.univetbantara.ac.id/index.php/komdik/article/view/113.

Trianto. (2017). Mendesain Model Pembelajaran Inovatif, Progresif, dan Kontekstual (ke-3). Jakarta: Kencana.

Yusuf, M. (2015). Quantitative, Qualitative \& Research Methods. Combined. Jakarta: Kencana.

Zikra. (2016). Analysis of Factors Causing Difficulty in Learning Biology for Class VII Students of Mts PGAI Padang. Journal of BioCONCETTA, 2(2). https://doi.org/10.22202/bc.2016.v2i2.1539. 